International Journal of Social Science (IJSS)

Vol.1 Issue.4 December 2021, pp: 279-288

ISSN: 2798-3463 (Printed) | 2798-4079 (Online)

\title{
INTERACTIVE POWERPOINTS IN ONLINE TGT-BASED MODELS ON THERMOCHEMICAL MATERIALS
}

\author{
By \\ Ratna Kusumawardani ${ }^{1}$, Muhamad Hamami Nata $^{2}$, Iis Intan Widiyowati ${ }^{3}$ \\ ${ }^{1,2,3}$ Chemical Education, Faculty of Teacher Training and Education, Mulawarman University \\ Email: ${ }^{1}$ nana_chemistry@yahoo.com
}

\begin{tabular}{|c|c|}
\hline Article Info & ABSTRACT \\
\hline Article history: & The closure of schools due to the Covid-19 pandemic has forced all schools in \\
\hline Received July 9, 2021 & Indonesia to be closed temporarily, therefore learning must be carried out online. \\
\hline Revised August 20, 2021 & Online learning is commonly carried out with teacher presentations and assignments \\
\hline Accepted Sept 11, 2021 & $\begin{array}{l}\text { therefore this makes learning monotonous and boring for students. So we need a } \\
\text { medium that makes learning more interesting, namely with interactive powerpoints. }\end{array}$ \\
\hline & The purpose of this study was to determine the effect of using interactive \\
\hline Keywords: & powerpoints in the online-based TGT model on thermochemistry material. This type \\
\hline Interactive powerpoint & of research is quasi-experimental research with a post-test only control group \\
\hline Online learning & design. The data collection technique used the technique of daily test tests, \\
\hline TGT Model & $\begin{array}{l}\text { aocumentaton, and stuaent percepton questionnatres. Ine adta were analyzea } \\
\text { using the normality test, } F \text { test, and t test with a significance level of 5\%. The results }\end{array}$ \\
\hline & showed that before being given the treatment, the two classes were normally \\
\hline & $\begin{array}{l}\text { distributed, homogeneous variations and there was no difference in student } \\
\text { absorption. After being given the treatment, the two classes had significant } \\
\text { differences in absorption. Therefore it can be concluded that there is an effect of }\end{array}$ \\
\hline & $\begin{array}{l}\text { using interactive powerpoints in the online-based TGT model on thermochemistry } \\
\text { material. }\end{array}$ \\
\hline
\end{tabular}

This is an open access article under the CC BY-SA license.

Corresponding Author:

Ratna Kusumawardani

Faculty of Teacher Training and Education,

Mulawarman University,

Email:nana_chemistry@yahoo.com

\section{INTRODUCTION}

Thermochemistry as a part of chemistry has been studied since high school through chemistry subjects. However, according to research conducted by Zakiyah, et al. [1]chemistry is a difficult subject for most high school students. The results of the study stated that the cause of chemistry is considered difficult because chemistry requires abstract thinking skills, requires mastery of mathematics, and has tiered concepts. These three factors are contained in the thermochemical material in which students will learn about heat, and calculate enthalpy changes with the help of stoichiometric concepts. Based on the results of research Verdina, et al. [2], Hidayat [3] and Aprialisa and Mahdian[4], it is known that students' understanding of thermochemistry is still relatively low because most students do not reach the school'srequired standard.

Chemistry subjects that are considered difficult by students make chemistry lessons often associated with boredom, reluctance and failure for some students [5]. Chemistry lessons are associated with failure because according to Putri's research [6], thermochemical material is categorized as difficult material for students to understand. This is because the thermochemical material contains more computational material, while the majority of students avoid subject matter that contains calculations. In addition, the lack of variety of learning models carried out by teachers can make chemistry learning in class unattractive for students, causing boredom and reluctance. This shows that a variety of learning models are needed to help students understand the material. 
Thermochemistry learning is better when implemented using a cooperative learning model, one of the variations of learning models that can be used by teachers to learn is the Teams Game Tournament (TGT) learning model as stated by Doymus, et al. [7]. The TGT learning model is one type of cooperative learning model that involves collaboration between students so that it focuses on students. This model also emphasizes games and tournaments between students to increase student learning motivation and change learning to be not monotonous so that it is not boring and is expected to improve student learning outcomes. The advantages of this model are that it can increase the motivation and participation of students with low academic abilities, foster a sense of togetherness and mutual respect, and increase students' enthusiasm for learning. In addition, according to Ravinah and Kusumawardani [8] the existence of a tournament in this model makes learning more fun, students are more relaxed, and fosters a sense of responsibility and healthy competition.

The TGT model is included in student-centered learning, it also has its own problems [9]. Students will discuss with each other and make the teacher's task to gather attention from students more difficult, so we need a learning media that can attract students' attention so that they can pay attention to the direction of the teacher and do the learning stages well.

Focusing students' attention can be helped by using learning media. Learning media is very diverse, one of which is powerpoint. Powerpoint media has the advantage that it can help achieve learning goals more effectively, help present abstract concept messages for students to be clearer, thorough, and interesting, can create a learning environment that is not monotonous, and can increase student learning motivation. PowerPoint media has been widely used to improve student learning outcomes, including research by Anita [10] and Warass [11] showing the use of powerpoint media can improve student learning outcomes. Furthermore, the results of research by Kartikasari and Nugroho [12] show that the use of interactive powerpoint can make students excited to learn, focus on learning, and improve learning outcomes. Interactive Powerpoint is very effective to be used as a learning medium. This is supported by Dewantara's research [13], resulting in a difference in the average student learning outcomes in Biology subjects, where the class that uses powerpoint media gets a score of 91.56 and the class that does not use powerpoint gets a score of 68.39 .

Learning outcomes are also influenced by the way of teaching and learning carried out by students and teachers. The pandemic situation that occurred throughout 2020 forced a change in the way of teaching and learning for students and teachers around the world. Learning, which is generally done directly in schools, now has to be done remotely. This makes learning that is generally outside the network (offline) into learning that is carried out in a network (online). The solution that can be done by teachers is to do online learning with the help of websites or learning applications.

One of the applications and websites that have been widely used is Edmodo. Edmodo can be used to create virtual classrooms for teachers and students. Previous research, conducted by Arham and Dwiningsih [14] showed that the use of Edmodo can be used as a medium to carry out online learning.

The closure of the school at MAN 1 Samarinda due to the Covid-19 pandemic caused learning to be done online. Based on this description, researchers are interested in examining the effect of using interactive powerpoint learning media in the online TGT learning model on student learning outcomes on thermochemistry material at MAN 1 Samarinda.

\section{RESEARCH METHOD Research Design}

The type of research used is a quasi-experimental design using one experimental or treatment class and one control class, which aims to see the effect on student learning outcomes in both classes. The design used is a staticgroup comparison design. The implementation of this research was carried out by giving treatment to the experimental class in the form of using interactive powerpoint learning media with both classes using the TGT model.

\section{Research Target}

The target of this research is students in class XI IPA 1 and XI IPA 3 MAN 1 Samarinda, each class consists of 36 students.

\subsection{Research Data}

The research data used in this study are data on student test scores, teacher and student activity data, as well as data on student responses to online learning and thermochemistry learning carried out by researchers. Student test results are obtained through tests carried out by students on thermochemical material. The results of teacher and student activity data are generated from the observation process by the observer. Student response data obtained through a questionnaire given after the entire learning process has been implemented. 
International Journal of Social Science (IJSS)

Vol.1 Issue.4 December 2021, pp: 279-288

ISSN: 2798-3463 (Printed) | 2798-4079 (Online)

DOI: https://doi.org/10.53625/ijss.v1i4.4702

\subsection{Research Instruments}

The instruments used in this study were documentation, observation sheets, test questions, and questionnaires.

\subsubsection{Dokumentasi}

Documentation is used to obtain information about student grades obtained from chemistry teachers regarding daily chemistry tests on the hydrocarbon solution material used to perform homogeneity tests, determine the division of groups so that they are heterogeneous and to find out the list of names of students in class XI MAN 1 Samarinda who were used as research objects.

\subsubsection{Observation sheet}

The observation sheet consists of a student observation sheet and a teacher observation sheet, both of which are useful for knowing the teaching activities carried out by the teacher and the activeness of students during the learning process. The teacher's observation sheet uses the Guttman scale while the student's observation sheet uses the Likert scale.

\subsubsection{Test Questions}

The test technique used is formative test/daily test. This test was carried out at the fourth meeting, namely after all the material ended, 20 multiple choice questions were given. Daily test questions are made based on learning indicators in all meetings. This test was carried out by all students in the control class and the experimental class.

\subsubsection{Questionnaire}

Questionnaires on students' perceptions of online learning and the use of interactive powerpoints were given to students after the entire learning process ended. Questionnaires were given to students via google forms. In filling out this questionnaire, the researcher gave a statement, then the students chose the statement of disagree, agree or strongly agree with the statement. In addition to choosing disagree, agree and strongly agree, students were also asked to explain the reasons for their choice.

\subsection{Data Analysis Techniques}

\subsubsection{Data Analysis of Student Test Results}

Data analysis on student test results was carried out on the results of daily tests of thermochemistry subjects. The data was processed statistically, using the Liliefors test, $\mathrm{F}$ test and t test. The Liliefors test was used to see whether the data used were normally distributed or not, then tested using the $\mathrm{F}$ test to see whether the sample was homogeneous or heterogeneous, and finally tested using the $t$ test to compare whether there was a difference in absorption in the two classes before treatment and whether there was an effect of using media. interactive powerpoint learning after treatment.

\subsubsection{Observation sheet}

Data processing from student observation sheets in both classes is calculated using the formula:

$$
\mathrm{P}=\text { score } /(\text { total maximum score }) \times 100 \%
$$

Based on the resulting percentage of learning activities in both classes, the results are then categorized according to the percentage table of student activities according to [15] below.

Table 1. Percentage of Student Activity in Learning

\begin{tabular}{c|c}
\hline Percentage $(\%)$ & Category \\
\hline $0-20$ & Very less \\
\hline $21-40$ & Less \\
\hline $41-60$ & Enough \\
\hline $61-80$ & Good \\
\hline $81-100$ & Very good \\
\hline
\end{tabular}




\section{RESULTS AND ANALYSIS}

\subsection{Learning Outcomes of Experiment Class and Control Class}

Student learning outcomes in the experimental class and control class were taken from the daily test scores conducted at the fourth meeting. Learning in the experimental class and control class is carried out using the TGT model and through the Edmodo application, the difference between the two is that in the experimental class the learning process is assisted by using interactive powerpoint learning media. The learning outcomes can be seen in the following figure:

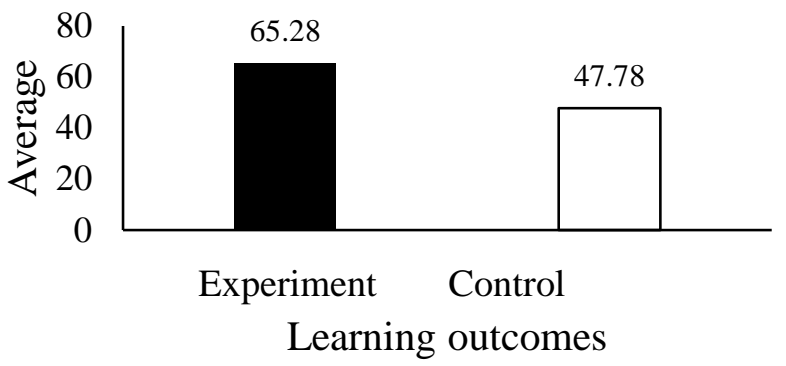

Figure1. Average Value of Learning Outcomes from Experiment Class and Control Class

Based on Figure 1, it can be seen that the learning outcomes of the experimental class are higher than the control class. This can happen because with the interactive powerpoint in the experimental class, the tournament and learning process as a whole becomes more interesting than in the control class which only uses google forms. Experimental class students get a game display that is different from other assignments so it doesn't feel monotonous, additional visuals and audio are more interesting, as well as discussion of questions. This can be seen from the number of students participating, the number of students participating in the experimental class is more than the control class, and the total score obtained in the experimental class is also higher. This is because the use of interactive powerpoint media can increase students' interest and motivation. The results on the questionnaire given by the researcher are depicted in the following diagram:

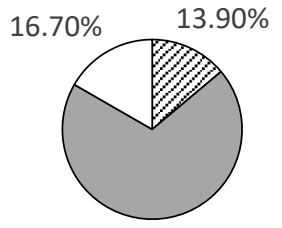

$69.40 \%$
飞 Very agree
$\sqsubset$ Agree
Disagree

Figure2. Diagram of students' perceptions of the influence of powerpoint interactive on interest and motivation to learn

The results of the questionnaire in Figure 2 as many as $69.40 \%$ of students agreed that interactive powerpoint media for thermochemical materials could increase students' interest and motivation in learning. One of the factors that influence student interest and learning is a varied or different learning process from the previous one [16]. In this case, interactive powerpoint can make a difference in the learning process because it has a non-monotonous display, a more attractive color display with a blend of colors, more varied images, and additional audio when students are working on questions, answering correctly or when students answer incorrectly. question. This is in accordance with the statement of Darmawan [17] which states that interactive powerpoint media can increase students' learning motivation. This is also evidenced by the research of Saida, et al [18] which shows an increase in student learning motivation due to the use of interactive powerpoints and Nursyam's research [19] which states an increase in student interest in learning due to the use of learning media. 
International Journal of Social Science (IJSS)

Vol.1 Issue.4 December 2021, pp: 279-288

ISSN: 2798-3463 (Printed) | 2798-4079 (Online)

Another factor that causes the value of learning outcomes in the experimental class to be higher is the feedback provided by interactive powerpoint. When the experimental class students answer incorrectly from the questions given in interactive powerpoint, the interactive powerpoint will raise a voice stating that it is wrong and provide discussion of the questions by showing the stages of working on the right questions This was not obtained for control class students who when they answered incorrectly, they would only be told that the answer was not quite right without any discussion at all. This increase is supported by the findings of Nahadi, et al [20], Vollmeyer and Rheinberg [21], and Febriyanti [22] which state that feedback provided by teachers can improve student performance during the learning process. Thus, feedback not only serves to determine the progress and difficulties of student learning, but can also increase students' self-confidence. Feedback is teacher behavior to help students who have learning difficulties individually by responding to student work, so that students become better at mastering the material presented. This teacher's behavior is outlined in a more interesting discussion contained in interactive powerpoint media.

\subsection{The Effect of Using Interactive Powerpoint Media on Learning Outcomes}

The effect of using interactive powerpoint on student learning outcomes can be proven through statistical tests. Statistical tests used were liliefors test, $\mathrm{F}$ test, and $\mathrm{t}$ test. The test results are as follows:

Table 2. Results of Data Analysis After Treatment

\begin{tabular}{cccccccc}
\hline \multirow{2}{*}{ Class } & \multirow{2}{*}{ Score } & \multicolumn{2}{c}{ Liliefors test } & \multicolumn{2}{c}{$\mathrm{F}$ test } & \multicolumn{2}{c}{$\mathrm{T}$ test } \\
\cline { 3 - 8 } & & $\mathrm{L}_{\text {count }}$ & $\mathrm{L}_{\text {table }}$ & $\mathrm{F}_{\text {count }}$ & $\mathrm{F}_{\text {table }}$ & $\mathrm{t}_{\text {count }}$ & $\mathrm{t}_{\text {table }}$ \\
\hline Experiment & 65,28 & 0,10 & 0,11 & 1,97 & 1,78 & 5,39 & 1,67 \\
Control & 47,78 & & & & & & \\
\hline
\end{tabular}

Based on Table 2, the results of the Liliefors statistical test, show the value of Lcount $<$ Ltable, which indicates that $\mathrm{HO}$ is accepted, the sample is normally distributed, then the value of Fcount $>$ Ftable, so that $\mathrm{H}_{0}$ is rejected and the variance of both is heterogeneous. Then the t-test performed showed that tcount $>$ ttable, so the hypothesis $\mathrm{H}_{\mathrm{a}}$ was accepted and proved that there was an effect of interactive powerpoint learning media in the online-based TGT learning model on student learning outcomes at MAN 1 Samarinda on the subject of thermochemistry.

\subsection{The Value of Student Learning Outcomes is Still Below School's Required Standard}

The value of student learning outcomes on thermochemical material in the experimental class and control class is still below the MAN 1 Samarinda required standard. Based on the researchers' observations, the school's required standard score at MAN 1 Samarinda was 75, higher than the learning outcomes in the experimental class (65.28) and the control class (47.78). This is greatly influenced by the condition of students who have to study online at home due to the Covid-19 pandemic. This is because there are several things that can affect student learning outcomes related to the condition of students when studying online. This condition was obtained by the researcher from a questionnaire filled out by students.

The first problem faced by students while studying online at home is worrying about the Covid-19 pandemic. Of the total 68 students used as samples, 91\% are worried about the development of the virus in Indonesia. Furthermore, $92.6 \%$ expressed concern that their family members would be exposed to this virus. This certainly affects the psychological condition of students at the time of learning. Where the psychological condition of students is very influential on student learning outcomes. Psychological conditions are internal factors that affect student learning outcomes. This is in accordance with the results of research conducted by Mardatila [23] that student learning outcomes in Integrated Thematic Social Studies subjects are influenced by psychological factors by $71 \%$ and $29 \%$ are influenced by other student factors.

Not only due to the corona virus, the psychological condition of students is also affected by the closure of schools due to Covid-19. Research by Ardan, et al [24] states that due to school closures, students become more easily tired and bored. This also happened to the experimental class and control class which based on the results of the questionnaire showed $75 \%$ of students felt bored while studying at home, with the most frequent reason being that they had difficulty socializing, both for discussion and for joking between lessons. However, not a few students also feel more comfortable when studying at home because they can study more calmly and can concentrate better.

Comfortable conditions when studying at home are one of the advantages of learning at home, unfortunately this is only felt by a small number of students. Research by Nugroho, et al [25] shows that one of the problems faced 
by students is the difficulty of having a comfortable psychological condition when studying online. This was also felt by students in the experimental class and control class, $91 \%$ of students stated that they had difficulty concentrating when learning online. The reasons given by students also varied, such as interference from cellphones and tv, helping younger siblings to study, monotonous teaching methods, tired of looking at screens all day and the most frequently stated was homework that had to be done simultaneously with the learning process. Cahyani, et al [26] explained that the conditions of the learning environment were not conducive and the difficulty of finding time to study for students caused student motivation to decrease.

Decreased student motivation increasingly makes students reluctant to study independently. This is not good, because the success of online learning is strongly influenced by the independence of students, as stated by Nugroho, et al [25]. The low independence of students during online learning occurs because students are not ready to learn independently, because they are still accustomed to teacher guidance in a teacher-centered classroom [27]. The impact of this is that students become overwhelmed when doing assignments. Questionnaires on students showed students were overwhelmed when doing assignments. The number of students who feel overwhelmed when working on assignments from all subjects is illustrated by the following graph:

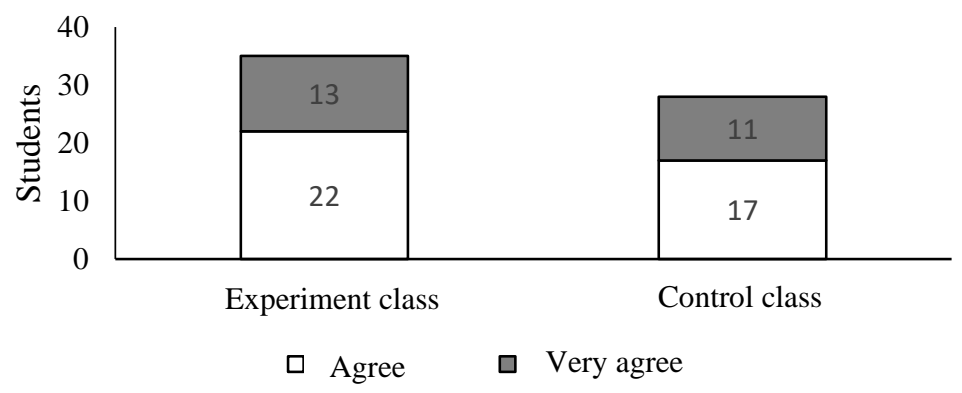

Figure 3. Students' Perception of Tasks during Online Learning

Based on the results of the questionnaire, students stated that this feeling of being overwhelmed was due to the short deadline for collecting assignments and colliding with each other, plus a lack of understanding of the material provided, and difficulty in asking questions. In addition, students also feel overwhelmed because the tasks given by the teacher are too many. As many as $94 \%$ of students stated that the assignments given during online learning were too many. This feeling of being overwhelmed then makes students more emotional than usual, such as being more easily sad, confused, and even annoyed. This feeling can affect the psychological condition of students which can affect student learning outcomes. Psychological conditions that are not good will result in poor learning outcomes, and vice versa.

Based on the explanation above, the researcher then asked more specifically about how students perceive the learning process in the thermochemistry chapter. Opinions of the experimental class and control class are illustrated by the following graph:

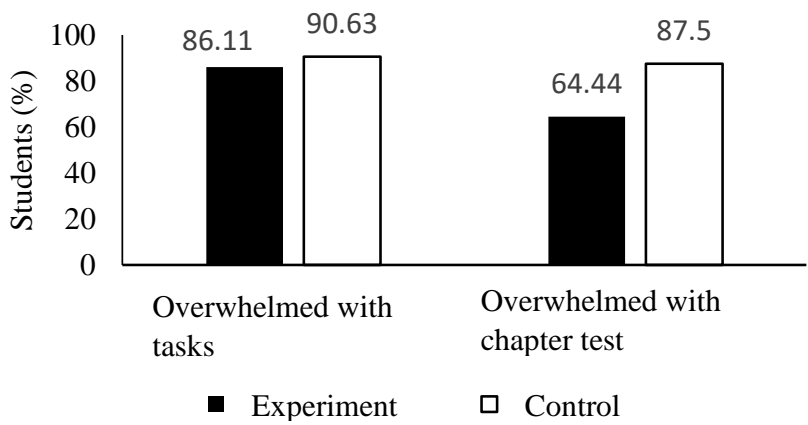

Figure 4. Persepsi Siswa terhadap Materi TermokimiaMateri

The graph above shows that students feel overwhelmed by the many assignments given by the teacher in this thermochemistry chapter. In addition, students also find it difficult when working on daily test questions given by the teacher. Consistently, the number of students who felt overwhelmed or had difficulty in the thermochemistry chapter in the control class was higher than the experimental class which was assisted by interactive PowerPoint media.

The feeling of being overwhelmed by students is also influenced by the thermochemical material which from the beginning has become one of the materials considered difficult by students. Sutisna [28] stated that the average 
International Journal of Social Science (IJSS)

Vol.1 Issue.4 December 2021, pp: 279-288

ISSN: 2798-3463 (Printed) | 2798-4079 (Online)

DOI: https://doi.org/10.53625/ijss.v1i4.4702

value of students' tests on thermochemical material was the lowest compared to other class XI chemistry materials. The research by Dewi, et al [29] shows that most of the students score below the school's required standard and more specifically the research by Rednasari [30] states that $48.8 \%$ of the students have not achieved the school's required standard. score. In addition, learning must be carried out online, making thermochemistry learning more difficult. Yulia and Putra [31] in their research on students' difficulties in learning mathematics online stated that online learning made students feel difficult, reluctant to participate actively, and easily gave up on problems that had difficulties or errors. The questionnaire given by Farida, et al [32] to their students resulted in a statement in the form of chemistry learning that was deemed unsuitable for chemistry learning and some students stated that they did not like online learning.

Based on the explanation above, the use of interactive powerpoint media in the online TGT model on thermochemical material has an influence on student learning outcomes at MAN 1 Samarinda. This is because in interactive powerpoint media students can interact directly with the media, get a non-monotonous display, additional visuals and audio that are more interesting, and get feedback in the form of discussing questions when incorrectly answered instantly. Meanwhile, student learning outcomes that are still less than the school's required standard can be caused by several factors. The factors in question are the conditions of the learning environment that are not conducive, too many assignments, short deadlines, the questions given are still too difficult, and students' unpreparedness to study independently. This condition causes students to become more emotional, anxious, and decreased motivation to learn.

\section{CONCLUSION}

The conclusion obtained is that there is an influence of interactive PowerPoint learning media in the online TGT learning model on the learning outcomes of class MAN 1 Samarinda students on the subject of thermochemistry. Suggestions for further research are to give questions with gradually increasing difficulty levels, provide sufficient assignments during a pandemic and focus more on communication with students, and choose learning models that are easier to implement when online.

\section{ACKNOWLEDGEMENTS}

The researcher would like to thank all those who have helped in the process of this research, especially to MAN 1 Samarinda who have permitted for me to conduct research.

\section{REFERENCES}

[1] Zakiyah, S. Ibnu, and Subandi, “Analisis Dampak Kesulitan Siswa pada Materi Stoikiometri Terhadap Hasil Belajar Termokimia," EduChemia (Jurnal Kim. dan Pendidikan), vol. 3, no. 1, pp. 119-134, 2018.

[2] R. Verdina, A. Gani, and Sulastri, "Improving students' higher order thinking skills in thermochemistry concept using worksheets based on 2013 curriculum," J. Phys. Conf. Ser., vol. 1088, 2018, doi: 10.1088/1742-6596/1088/1/012105.

[3] S. Hidayat, "Pengaruh Model Problem Based Learning terhadap Hasil Belajar Kimia Siswa pada Konsep Termokimia," Jakarta, 2011.

[4] M. Aprialisa and Mahdian, "Meningkatkan Pemahaman Matematika Siswa Melalui Model Pembelajaran Kooperatif Tipe Two Stay Two Stray,” QUANTUM. J. Inov. Pendidik. Sains, vol. 1, no. 1, p. 41, 2010, doi: 10.17509/md.v11i1.3788.

[5] Nurhadi, Pembelajaran Kontekstual dan Penerapannya dalam KBK. Malang: Universitas Negeri Malang, 2004.

[6] S. D. Putri, "Pengembangan Modul Berorientasi unity of Sciences dengan Pendekatan Contextual Teaching and Learning pada Materi Termokimia," Semarang, 2016.

[7] K. Doymus, U. Simsek, A. Karaçöp, and S. Ada, "Effects of two cooperative learning strategies on teaching and learning topics of thermochemistry," World Appl. Sci. J., vol. 7, no. 1, pp. 34-42, 2008.

[8] W. R. Ravinah and R. Kusumawardani, "PENGARUH MEDIA MONOPOLI TERHADAP HASIL BELAJAR SISWA SMA INFLUENCE OF MONOPOLY TOWARD LEARNING OUTCOMES OF HIGH SCHOOL STUDENT ON THE SUBJECT OF Penelitian ini bertujuan untuk mengetahui pengaruh media monopoli dalam model pembelajaran kooperatif tipe tea," vol. 2, no. 2, pp. 20-23, 2019.

[9] M. A. Ramdhani, "Perbandingan Strategi Pembelajaran Teacher Centered Learning Dengan Student Centered Learning Terhadap Hasil Belajar Pada Mata Pelajaran Tarikh Siswa Kelas Viii Smp Muhammadiyah 4 Surakarta,” 2014, no. 1, p. 18, 2014.

[10] I. Anita, "Pengaruh Penggunaan Media Interaktif Komputer terhadap Hasil Belajar Siswa pada Materi Larutan Penyangga di SMA Negeri 1 Pasie Raja," Banda Aceh, 2015.

[11] R. D. Warass, "Pengaruh Media Pembelajaran Microsoft Powerpointterhadap Hasil Belajar Siswa pada Mata Pelajaran Akuntansi Kelas I SMA Pasundan 2 Kota Cimahi," Bandung, 2016.

[12] D. Kartikasari and G. K. Nugroho, "Media Pembelajaran Interaktif Mata Pelajaran Bahasa Jawa Pokok Bahasan Aksara Jawa pada Sekolah Menengah Pertama Negeri 2 Tawangsari Kabupaten Sukoharjo," J. SPEED Sentra Penelit. Eng. dan Edukasi, vol. 2, no. 3, pp. 1-6, 2010. 
[13] R. B. Dewantara, T. Jalmo, and Y. Berti, "Pengembangan Animasi Flash dengan Soal Interaktif Berbasis Powerpoint Materi Sistem Pernapasan Manusia Kelas XI,” Pros. Smnas Pendidik. IPA Pascasarj. UM, vol. 1, 2016.

[14] U. U. Arham and K. Dwiningsih, "Kelayakan Multimedia Interaktif Berbasis Blended Learning pada Materi Pokok Kimia Unsur," UNE, vol. 5, no. 2, pp. 345-352, 2016, doi: 10.1017/CBO9781107415324.004.

[15] S. Arikunto, Dasar-Dasar Evaluasi Pendidikan. Jakarta: Bumi Aksara, 2009.

[16] K. D. Ningrum, "Upaya Meningkatkan Minat Belajar Siswa Melalui Penggunaan Media Audio Visual Pada Siswa Kelas V Di Sdn Manggarai 09 Pagi ...,” Pros. Semin. Dan Disk. Pendidik. ..., pp. 307-313, 2018.

[17] D. Darmawan, Teknologi Pembelajaran. Bandung: PT. Remaja Rosdakarya, 2011.

[18] L. N. Saida, S. H. Wijoyo, and S. A. Wicaksono, "Pengaruh Penggunaan Media Pembelajaran Interaktif Berbasis Powerpoint untuk Meningkatkan Motivasi Belajar, Kebiasaan Belajar, dan Hasil Belajar Siswa di SMK Negeri 3 Malang,” J. Pengemb. Teknol. Inf. dan Ilmu Komput., vol. 3, no. 9, pp. 8695-8705, 2019.

[19] A. Nursyam, "Peningkatan Minat Belajar Siswa Melalui Media Pembelajaran Berbasis Teknologi Informasi," Ekspose J. Penelit. Huk. dan Pendidik., vol. 18, no. 1, pp. 811-819, 2019, doi: 10.30863/ekspose.v18i1.371.

[20] Nahadi, H. Firman, and J. Farina, "Effect of feedback in formative assessment in the student learning activities on chemical course to the formation of habits of mind," J. Pendidik. IPA Indones., vol. 4, no. 1, pp. 36-42, 2015, doi: 10.15294/jpii.v4i1.3499.

[21] R. Vollmeyer and F. Rheinberg, "A surprising effect of feedback on learning," Learn. Instr., vol. 15, no. 6, pp. 589-602, 2005, doi: 10.1016/j.learninstruc.2005.08.001.

[22] C. Febriyanti, "Pengaruh Bentuk Umpan Balik dan Gaya Kognitif terhadap Hasil Belajara Trigonometri," Form. J. Ilm. Pendidik. MIPA, vol. 3, no. 3, pp. 203-214, 2015, doi: 10.30998/formatif.v3i3.125.

[23] A. P. Mardatila, "Pengaruh faktor psikologi dan faktor sekolah terhadap hasil belajar siswa di smpn 1 Tanjungsari," Universitas Lampung, 2017.

[24] M. Ardan, F. F. Rahman, and G. B. Geroda, "The influence of physical distance to student anxiety on COVID-19, Indonesia," J. Crit. Rev., vol. 7, no. 17, pp. 1126-1132, 2020, doi: 10.31838/jcr.07.17.141.

[25] W. Nugroho, E. R. Malinda, M. J. Mustika Rani, and B. Basori, "An Exploratory Study on Implementation of Online Learning by Students During the COVID-19 Pandemic," Pancar. Pendidik., vol. 9, no. 2, pp. 25-38, 2020, doi: 10.25037/pancaran.v9i2.288.

[26] A. Cahyani, I. D. Listiana, and S. P. D. Larasati, "Motivasi Belajar Siswa SMA pada Pembelajaran Daring di Masa Pandemi Covid-19," IQ (Ilmu Al-qur'an) J. Pendidik. Islam, vol. 3, no. 01, pp. 123-140, 2020, doi: 10.37542/iq.v3i01.57.

[27] F. Magfiroh, A. N. Wahyudi, R. Putri, and N. Puji, "Analysis of Changes in Student Activity and Learning Patterns During the Pandemic: Case Study of High School Students in Jember Regency," vol. 9, no. 3, pp. 11-22, 2020, doi: 10.25037/pancaran.v9i3.297.

[28] A. Sutisna, "... Konflik Kognitif Untuk Memfasilitasi Perubahan Konseptual Dan Peningkatan Keterampilan Berpikir Kritis Siswa Pada Materi termokimia," Universitas Pendidikan Indonesia, 2013.

[29] K. M. Dewi, I. W. Suja, and I. D. K. Sastrawidana, "Model Mental Siswa Tentang Termokimia," J. Pendidik. Kim. Undiksha, vol. 2, no. 2, p. 45, 2018, doi: 10.23887/jjpk.v2i2.21165.

[30] E. P. Rednasari, "Deskripsi Kesulitan Belajar Siswa Kelas XI IPA Pada Materi Termokimia di Mas Ar-Risalah Padang," Universitas Negeri Padang, 2019.

[31] I. B. Yulia and A. Putra, "Kesulitan Siswa Dalam Pembelajaran Matematika Secara Daring," Refleks. Pembelajaran Inov. Vol. 2, No. 2, 2020, vol. 2, no. 2, pp. 327-335, 2020.

[32] I. Farida, R. R. Sunarya, R. Aisyah, and I. Helsy, "Pembelajaran Kimia Sistem Daring di Masa Pandemi Covid-19 Bagi Generasi Z,” KTI UIN Sunan Gunung Djati, pp. 1-11, 2020. 